\title{
Querelas e aquarelas do Brasil: o jazz na mira do nacionalismo musical (anos 1920-1960) ${ }^{1}$
}

\author{
Brazilian quarrels and aquarelles: jazz targeted \\ by musical nationalism (1920s-1960s)
}

Adalberto Paranhos ${ }^{2}$ Universidade Federal de Uberlândia/CNPq akparanhos@uol.com.br

Eu digo adeus ao boogie-woogie Woogie-boogie e ao swing também

Chega de rocks, fox-strots e pinotes

Que isso não me convém

Eu vou voltar pra cuíca

Bater na barrica e tocar tamborim

Chega de lights, all rights

Fights e good nights

Isso não tá mais pra mim

Eu quero um samba feito só pra mim

"Adeus, América" (Geraldo Jacques e Haroldo Barbosa), 1948. 


\section{Resumo}

É comum estabelecer-se uma associação imediata entre a propalada "influência do jazz" e a emergência e consolidação da Bossa Nova. Este artigo, no entanto, empreende uma viagem de volta no tempo e pretende documentar, de forma analítica, como as lutas de representações travadas entre setores que cultuavam a tradição e a brasilidade e outros que se apresentavam como modernizantes antecederam em muito aquela época. Para tanto, num apanhado geral, retrocede ao período pós-Primeira Guerra Mundial a fim de flagrar a eclosão das jazz bands, que na "era do jazz", nos anos 1920, estenderam seu raio de alcance a diferentes pontos do Brasil, incluindo cidades interioranas. Em sua marcha ascendente, a penetração de elementos musicais estadunidenses prosseguiu, especialmente na década de 1930, num momento em que o fox-trot se converteu no gênero de música estrangeira mais gravado no país. Na esteira desse fenômeno, este texto objetiva, então, capturar as reações ao que foi entendido como um processo de desnacionalização da música popular brasileira, que culminaria com a preparação de terreno para a "desfiguração" do samba "autêntico" promovida pelo samba-canção e pela Bossa Nova.

Palavras-chave: jazz; nacionalismo musical; tradição; modernidade; identidade nacional.

\section{Abstract}

An immediate association is usually established between the proclaimed "influence of jazz" and the emergence and consolidation of Bossa Nova. This paper, however, travels in time with the intention of documenting analytically how representation struggles between, on the one hand, sectors revering tradition and Brazilianness and, on the other, those presenting themselves as modernizing date back from before that era. To this end, the author proposes an overview of the post WW1 period to spot the rise of jazz bands, which, in the "jazz age" (the 1920s), extended their reach to different areas across Brazil, including inland cities. On their rising trajectory, American musical elements continued to seep in, especially during the 1930s, when fox trot became the foreign music genre with the highest number of recordings in the country. In order to highlight this phenomenon, this article intends to capture the reactions to what was understood as a process of denationalization of Brazilian popular music, which would eventually pave the way to the "disfigurement" of "authentic" samba carried out by samba-canção and Bossa Nova.

Keywords: jazz; musical nationalism; tradition; modernity; national identity.

Este texto é resultado parcial de pesquisa em desenvolvimento, decorrente do projeto Batalhas culturais: o jazz na mira do nacionalismo musical (Brasil, anos 1910-1960), que se beneficia de bolsa PQ/CNPq

Mestre em Ciência Política pela Unicamp. Doutor em História pela PUC-SP, com pós-doutorado em Música pela Unicamp. Professor titular do Instituto de Ciências Sociais e do Programa de Pós-graduação em História da UFU. Pesquisador do CNPq. Professor visitante da Universidade de Lisboa. Autor, entre outros livros, de Os desafinados: sambas e bambas no "Estado Novo"(São Paulo: Intermeios/CNPq/Fapemig, 2016) e de O roubo da fala: origens da ideologia do trabalhismo no Brasil (2. ed. São Paulo: Boitempo, 2007). Editor de ArtCultura: Revista de História, Cultura e Arte. Autor de artigos e capítulos de livros publicados na Argentina, Brasil, Chile, Cuba, Estados Unidos, Inglaterra e Portugal. Ex-vice-presidente e ex-presidente da IASPM-AL (seção latino-americana da International Association for the Study of Popular Music). 
Nos anos 1960, a Bossa Nova rompeu de vez os diques que, sob vários aspectos, ainda represavam a expansão dos horizontes da música popular brasileira. Na esteira da enorme repercussão causada pelo seu carro-chefe "Chega de saudade", no final da década anterior, ela se espraiou mundo afora. Sobretudo no exterior, os bossa-novistas, com Antonio Carlos Jobim e João Gilberto à frente, angariaram mil e uma manifestações de admiração daqueles que se entregaram ao seu poder de sedução artística, a começar pelos músicos que compunham a nata do jazz made in USA (PARANHOS, 1990). No entanto, como que a atestar o dito popular de que nem sempre santo de casa faz milagres, no Brasil nem tudo foram flores na acolhida proporcionada à Bossa Nova. De um lado, seus cultores a enalteceram como o ajuste de contas do país com a modernidade musical. De outro, encararam-na como expressão de um crime de lesa-brasilidade pelo enlace "espúrio" que selou com o jazz. Por essa razão os puristas de plantão acionaram, com uma estridência até então sem igual, os sinais de alarme.

A trincheira da reação foi, em larga medida, encabeçada pelo crítico musical José Ramos Tinhorão. Em artigos publicados em jornais e revistas (muitos deles agrupados posteriormente em livros) nos anos 1960, ele investia pesado contra a Bossa Nova. Pudera! Tinhorão e outros que tais atingiam as raias da indignação ante o que ocorria no campo musical. Não admitiam assistir, impassíveis, à "intromissão indevida" do jazz e da música norte-americana como um todo na música popular brasileira ou - o que dá na mesma - ao distanciamento desta das nossas "raízes". Num texto sobre "Marcha e samba", inserido na Revista Civilização Brasileira, ele demonstrava sua total contrariedade com o que se poderia designar como involução do samba. Depois de percorrer seu itinerário por décadas a fio, o desfecho do artigo era um monumento à ortodoxia. Sem o menor pudor, Tinhorão se recusava a seguir adiante e tratar, mais especificamente, da Bossa Nova. Nas suas palavras, "surgiu no fim da década de 50 uma mudança de estrutura: o samba de bossa nova. Mas aí já se penetra na história do jazz, e o autor deste artigo só gosta de falar de música popular brasileira" (TINHORÃO, 1966a, p. 261).

Samba-canção e Bossa Nova eram atirados às feras, depreciados como representantes da "corrupção" dos costumes musicais populares. Nada estranhável, partindo de quem elevava o "nacional-popular" à categoria de bem supremo. Particularmente no caso da música bossa-novista, a fúria que se apossava de Tinhorão o levava a desqualificá-la como um produto bastardo, de pai desconhecido. Sabia-se, porém, quem era, "inegavelmente, sua mãe"; ela que fora gerada como "filha de aventuras secretas de apartamento com a música norte-americana" (TINHORÃO, 1966b, p. 17). Esse seria seu pecado mortal ou seu pecado original, tido como imperdoável num período em que, como relembra Roberto Schwarz (1987, p. 32), no front nacional-populista "reinava um estado de espírito combativo, segundo o qual o progresso resultaria de uma espécie de reconquista, ou melhor, da expulsão dos invasores".

Trocando em miúdos essas considerações, o que me interessa ressaltar, acima de tudo, é que, ao colocarem o jazz, de modo geral, sob sua alça de mira, as batalhas culturais desfechadas contra ele - e, por consequência, contra a Bossa Nova - objetivaram converter o "outro" no bode expiatório da afirmação de um certo nacionalismo musical. 
Não foi à toa que, com a emergência do movimento bossa-novista, nunca, jamais e em tempo algum, no Brasil, a música popular figurou no palco de debates públicos como por essa época ${ }^{3}$. Num momento em que o "popular" era identificado como "nacional"4 por muitos dos participantes ativos da cena política e cultural brasileira, o jazz e tudo o que a ele se vinculasse deveria ser combatido sem tréguas por se intrometerem na seara musical destes trópicos 5 .

Mas, sob a atmosfera política do nacional-populismo em vigor naqueles anos, as coisas não pararam por aí. Em 1962, a reação à "jazzificação" do samba se instalou nas próprias fileiras bossa-novistas, uma evidência de que a oposição samba x jazz não refletia apenas o ponto de vista dos que eram contra ou a favor da Bossa Nova. A realidade se mostrava algo mais complexa, incapaz de ser submetida a esquemas analíticos simplistas. Contraditoriamente, Carlos Lyra, um dos mais fecundos compositores da Bossa Nova, soltou seu grito de alerta em "Influência do jazz", que alcançou ampla reverberação:

\author{
Pobre samba meu \\ Foi se misturando, se modernizando \\ E se perdeu [...] \\ E o samba meio morto \\ Ficou meio torto \\ Influência do jazz [...] \\ Pobre samba meu \\ Volta lá pro morro \\ E pede socorro onde nasceu [...] \\ Vai ter que se virar \\ Pra poder se livrar \\ Da influência do jazz ${ }^{6}$
}

E a música, calcada nas características bossa-novistas, colidia intencionalmente com a letra, que desnudava o militante Carlos Lyra, ligado ao Centro Popular de Cultura (CPC) da União Nacional dos Estudantes (UNE), em tempos em que o nacionalismo e o anti-imperialismo andavam de mãos dadas.

Por essas e outras, ganhou força a ideia que superestima a relação jazz e Bossa Nova, a ponto de contribuir poderosamente para quase apagar as linhas de convivência que, ao longo da história, marcaram a aproximação entre o jazz e a música popular brasileira em geral. É como se, no limite, seus vínculos com a produção bossa-novista tivessem inaugurado uma nova era, cuja presença solar turvaria a nossa vista, impedindo-nos

3 Sobre acaloradas discussões que repercutiram na imprensa e em outros meios, v. BOLLOS, 2010, p. 145-236.

4 Ver, a propósito, GARCIA, 2007, cap. O CPC da UNE, bem como as obras, entre outros, de dois componentes do Iseb (Instituto Superior de Estudos Brasileiros), de matriz essencialmente nacionalista: CORBISIER, 1958, e SODRÉ, 1962. Para este autor, povo é uma categoria social elástica, capaz de abrigar até segmentos burgueses, desde que seus interesses se confundam com os pretensos interesses nacionais. Hall, imprime, em várias passagens, um tom de escracho, como quem escarnece dessa influência. Bem diferente seria a interpretação da mais jazzística das cantoras da Bossa Nova, Leny Andrade, que extrai da canção todas as consequências com um ar de quem não está nem aí com a denúncia da qual era portadora, inclusive enveredando pelo scat singing. Para um exame mais detalhado dessas e de outras gravações de "Influência do jazz", ver PARANHOS, 2004, p. 28-30. 
de enxergar outras dimensões do passado. Daí que este artigo, na sequência, após uma breve incursão pela questão das lutas de representações e pelas relações entre nação e música, puxa os fios dessa trama sobre as ressonâncias do jazz por estas bandas.

Em que pesem as inúmeras polêmicas desatadas a respeito da coabitação musical entre Bossa Nova e jazz, retrocedo, em rápidas pinceladas, até as primeiras décadas do século $X X$. $E$, avançando no tempo, enfatizo que, de há muito, a resistência à penetração, no Brasil, da música de procedência estadunidense se fez sentir, com maior ou menor virulência. Por vezes, repito, a impressão que se tem é de que a "influência do jazz" se expressaria especialmente no período bossa-novista. Ledo engano. Desde que o jazz é jazz (entenda-se o que se entender por jazz, que já foi denominado jaz, jass, jasz, jas ou jazze), ele viajou pelo mundo a bordo de partituras, de discos, do rádio e do cinema. E, ao dilatar seu raio de propagação, suscitou reações de setores nacionalistas.

Nessa caminhada, aqui traçada de forma panorâmica, o jazz foi recebido entre tapas e beijos. De um lado, houve quem o acolhesse de braços abertos, como um elemento oxigenador da cultura nacional. De outro, ele foi repudiado como um intruso que deveria ser escorraçado em nome da salvaguarda das mais caras tradições brasileiras. Tudo isso nos pôs frente a frente com lutas de representações, dotadas de forte carga simbólica.

\section{Representações e tensões: um campo minado}

As disputas travadas sobre os caminhos trilhados pela música popular brasileira e suas relações com o jazz nos colocaram diante de um campo minado de tensões a toda prova. Por esse motivo, abro, agora, um parêntesis, para adicionar uma pitada de teoria às discussões que vararam décadas em torno daquilo que seria ou não representativo do Brasil.

No fundo, uma série de representações sobre o que seria ou não "autenticamente nacional" desfilaram sob os nossos olhos durante o período abarcado por este texto. Isso me remete a uma concepção básica da História Cultural, tal como formulada, entre outros, por Roger Chartier: a leitura da realidade obedece sempre a uma determinada construção, que é, em última instância, uma representação. E, no emaranhado de representações, emergem campos tensionados por perspectivas e interesses distintos. Como num cabo de guerra, eles se embrenham em lutas de representações, como as que opuseram o samba e o jazz. Daí salientar Chartier (1990, p. 17):

As percepções do social não são de forma alguma discursos neutros [...] Por isso esta investigação sobre as representações supõe-nas como estando sempre colocadas num campo de concorrências e de competições cujos desafios se enunciam em termos de poder e de dominação. As lutas de representações têm tanta importância como as lutas econômicas para compreender os mecanismos pelos quais um grupo impõe, ou tenta impor, a sua concepção do mundo social, os valores que são os seus, e o seu domínio. Ocupar-se dos conflitos de classificações ou de delimitações não é, portanto, afastar-se do social - como julgou durante muito tempo uma história de vistas demasiado curtas -, muito pelo contrário, consiste em localizar os pontos de afrontamento tanto mais decisivos quanto menos imediatamente materiais. 
Aliás, uma das referências capitais no pensamento de Chartier, o sociólogo Pierre Bourdieu (2002a, p. 113 e 118), já advertira anteriormente para a relevância das lutas de representações. Ele insistia na necessidade "de se incluir no real a representação do real ou, mais exatamente, a luta das representações", pois a "'realidade' [...] é o lugar para uma luta permanente para definir a 'realidade'", o que supõe uma "luta para fazer existir ou 'inexistir' o que existe". Tais considerações deságuam num outro texto no qual Bourdieu (2002b, 185) diz que

A força das ideias [...] mede-se, não como no terreno da ciência, pelo seu valor de verdade (mesmo que elas devam uma parte da sua força à sua capacidade para convencer que ele detém a verdade), mas sim pela força de mobilização que elas encerram, quer dizer, pela força do grupo que as reconhece, nem que seja pelo silêncio ou pela ausência de desmentido, e que ele pode manifestar recolhendo as suas vozes ou reunindo-as no espaço?.

A força dessa ou daquela ideia sobre o samba ou o jazz não resultou, todavia, de uma iniciativa solitária nem foi obra que carregasse uma assinatura meramente individual. No caso específico desta pesquisa, ao interpelar o passado, verifica-se que o nacionalismo, a repulsa ao jazz, a exaltação do samba como artefato cultural "autenticamente" brasileiro e a rejeição à Bossa Nova são fios de uma meada que não se desembaraçam facilmente. Eles estavam entrelaçados numa rede autoral que comporta uma interlocução polifônica, tecendo um campo de reflexões habitado pelo dialogismo.

E o que se passa com as ideias afeta também, é lógico, as canções. Parto, assim, do princípio de que canção alguma é uma ilha, mantida em regime de clausura, como se fosse viável cortar os elos que a ligam a outras canções e a mil e um discursos e referências sociais. Sem que se perca de vista sua singularidade, quando alargamos a escala de observação de uma criação cultural, pode-se constatar que, dialeticamente, tudo se acha em interconexão universal, como que dialogando entre si. Em se tratando de uma canção, ela, para dizer o mínimo, está permanentemente grávida de outras canções com as quais entretém um constante diálogo, seja ele implícito ou explícito, consciente ou inconsciente.

Nessa linha de raciocínio, tomo como ponto de partida as contribuições de Mikhail Bakhtin (1981, 2004; BRAIT, 2001) contidas em seus estudos sobre dialogismo ou intertextualidade. E aqui, mais do que uma alusão genérica ao princípio dialógico constitutivo de toda e qualquer linguagem e de todo e qualquer discurso, apelo para o uso dessa ferramenta teórica e metodológica para demarcar o caráter socialmente ampliado de umas tantas ideias e representações sobre o samba, o samba-canção, a Bossa Nova e o jazz. Esse processo autoral polifônico se conecta, por outras vias, com o que viria a sustentar Michel Foucault em um de seus célebres escritos, "O que é um autor". Ao referir-se, por exemplo, ao dramaturgo Racine, ele, com base em Lucien Goldmann, afirma:

7 Sobre a "força das ideias", parece-me pertinente relacioná-la com certas formulações de Karl Marx e Antonio Gramsci. Como assinala o filósofo italiano, convém "recordar a frequente afirmação de Marx sobre a 'solidez das crenças populares' como elemento necessário de uma determinada situação. [...] Outra afirmação de Marx é a de que uma persuasão popular tem, com frequência, a mesma energia de uma força material, ou algo semelhante, e que é muito significativa" (GRAMSCI, 2001, p. 238). 
fui levado a mostrar que Racine não é sozinho o único e verdadeiro autor das tragédias racinianas, mas que estas nasceram no bojo do desenvolvimento de um conjunto estruturado de categorias mentais que era obra coletiva, o que me levou a encontrar como "autor" dessas tragédias, em última instância, a nobreza de toga, o grupo jansenista e, no interior deste, Racine como indivíduo particularmente importante (FOUCAULT, 2009, p. 290).

Sob esse prisma, procuro compreender as manifestações nacionalistas que atravessaram décadas perseguindo o propósito de promover uma cruzada de purificação da música popular brasileira. Muitos foram os "cruzados" que, em suas falas e ações de cunho transindividual, buscaram, a todo custo, afugentar o fantasma do jazz que assombrava o Brasil. Se não houve, como é comum, uniformidade absoluta nos argumentos que esgrimiram, seu alvo, porém, era o mesmo.

Seja como for, fecho este parêntesis dedicado a uma digressão teórica para destacar que determinadas formulações, correntes entre os anos 1920 e 1960, se afinavam inclusive com preocupações que remontavam ao século XIX, ao estabelecerem uma rede de interlocução de teor nacionalista. Criticou-se, desde então, tudo o que cheirasse a postiço, cópia, imitação do estrangeiro, e implicasse inadequação à nossa realidade cultural. Não foi o crítico literário Silvio Romero (1897, p. 121-123) que se insurgiu contra a "macaqueação", por ele identificada como um fato social dominante nos tempos pós-coloniais, principalmente no $2 \circ$ reinado?

\section{A "era do jazz" e as irrupções nacionalistas}

Numa obra tornada clássica, Benedict Anderson (2008), ao enfocar o surgimento e a difusão do nacionalismo e o sentimento de pertencimento a essa ou aquela nação, concebe as nações como comunidades políticas imaginadas. Como um de seus traços marcantes, os seus integrantes são tomados/imaginados como semelhantes, como se compartilhassem, de uma forma ou de outra, um lastro cultural comum. Sob esse aspecto, nação e nacionalismo, em certas circunstâncias históricas, como que se dão as mãos, a ponto de se produzirem o que Homi Babba (1990) designa como "narrativas pedagógicas da nação".

Nesse contexto, historicamente, é possível captar, em diversas situações, os nexos profundos que enlaçaram igualmente a música e o nacionalismo. Disso se ocuparam tanto historiadores quanto musicólogos. No primeiro caso, por exemplo, Tim Blanning (2011) chama a atenção, entre outras coisas, para a associação, muito recuada no tempo, entre as artes marciais e a música. No segundo, ao pensar o nacionalismo musical, sobretudo a partir da impulsão estatal, Julio Mendívil (2016, p. 93 e 95) frisa que "la música ha sido y sigue siendo un espacio predilecto para impulsar y difundir discursos nacionalistas" e emenda que "los nacionalismos requieren siempre de una amenaza 'foránea'". Nessa perspectiva, por sinal, a presença do "outro" é, a rigor, indispensável para a moldagem da identidade nacional, ao definir os termos básicos de uma contradição que, dialeticamente, constitui a unidade dos contrários própria da "dialética do nacionalismo" (BLANNING, 2011, p. 251, e 2007, p. 305-321). E foi o que se viu em meio à "era 
do jazz", carne viva de que se nutriram muitas irrupções nacionalistas, seja no Brasil, seja em outros cantos do mundo.

A expressão "era do jazz", que se situa em particular na década de 1920, foi empregada pela primeira vez pelo romancista Scott Fitzgerald (2003) por alusão a uma torrente de mudanças comportamentais. Num sentido lato, ela englobaria a celebração de uma época de efervescência cultural, de desintegração de valores tradicionais, de diversão, de modernidade, de velocidade e de alegria contagiante ${ }^{8}$. Sob essa ótica, a "era do jazz" transcende a seu enquadramento exclusivo no âmbito da música e da dança.

Musicalmente, seu berço por excelência, segundo os estudiosos, foi a New Orleans da virada dos séculos XIX e XX. O estilo dixieland, que lá despontou, acelerou a popularização da palavra jazz. Este, entretanto, era um imenso guarda-chuva que dava guarida a danças e gêneros de várias nomenclaturas como charleston, cakewalk, one-step, two-steps, shimmy, ragtime, fox-trot. E, no rastro de seu desenvolvimento e de sua aceitação social, ele aprofundou sua inserção na área das diversões.

Conforme Tim Blanning (2011, p. 128), pesquisador que sublinha as origens afro-americanas do jazz, "durante parte do século XX, apesar de toda a capacidade do jazz de expressar o sofrimento e as aspirações de uma comunidade oprimida, o gênero fez parte integral da indústria do entretenimento". Nesse cenário, no pós-Primeira Guerra Mundial - e, em especial, nos anos 1920 - assistiu-se à disseminação do jazz também pelos lados da América Latina. Na Argentina (PUJOL, 2004, caps. 1-3) ${ }^{9}$, no Chile (GONZÁLEZ; ROLLE, 2005, p. 538-574) e no Brasil, para não ir mais longe, ele se espalhou como um rastilho de pólvora. A isso se seguiria a febre das jazz bands, sinônimo de música dançante. Como anota o musicólogo Alberto lkeda (1984, p. 9), "pela década de 1920 afora proliferaram em diversas cidades do Brasil, até nas cidades interioranas, as formações instrumentais do tipo jazz-band"10. Elas traziam consigo os últimos passos da moda musical irradiada pelos Estados Unidos (o que não excluía necessariamente do repertório das jazz bands brasileiras gêneros propícios à dança e à explosão de alegria, como o samba e o maxixe).

Diante desse quadro, com o fox e o charleston em alta, houve até quem se visse na contingência, ante a proximidade do carnaval, de desencadear uma campanha em favor do maxixe, em 1928, como foi o caso do redator carnavalesco Arlequim, nas páginas de O Jornal do Rio de Janeiro. Ele argumentava, sem meias-palavras: "O próprio maxixe perdeu prestígio. O fox e o charleston deixaram-no abandonado e triste". Afastado do teatro ou dos clubes, "hoje não se dança mais o passo nacional" (apud TINHORÃO, 1986, p. 87-88).

O fox e o charleston eram dois tentáculos poderosos da "era do jazz", troncos de uma árvore frondosa que brotava em mil cantos e recantos do planeta. Sequer a música

8 Essa decantada "modernidade" foi vivenciada, em terras brasileiras, notadamente no Rio de Janeiro (SEVCENKO, 1998).

$9 \quad$ Ver a linha do tempo do jazz na Argentina em CORTI, 2015, p. 170-175. Sobre os anos 1920 nesse país, tidos como "tempos modernos", ver PUJOL, 2013, p. 36-39.

10 Ver um trabalho recente de Sinimbú (2019) a respeito da difusão dos jazzes (sim, este é o nome adotado no Pará para as jazz bands) no sudeste paraense. Sobre a proliferação das jazz bands no Rio de Janeiro e no Paraná, ver LABRES FILHO, 2014, e GILLER, 2013. 
erudita ou as óperas escaparam ilesas ante sua presença, quando não onipresença. $O$ jazz representou um sopro de renovação nas práticas musicais, ao pavimentar o caminho que conduziu a uma maior aproximação entre a música dita popular e a música "séria". Absorvido por compositores eruditos animados por propósitos antiwagnerianos, como Hindemith, Stravinsky e Satie, ele provocou novos giros nas engrenagens musicais. Uma sucessão de fatos artísticos como óperas-jazz e festivais realizados na Alemanha anunciava outros tempos, aos quais se associaram Kurt Weill e Bertolt Bretch, que o transpuseram para os palcos, ao celebrarem o seu sentido de emancipação do ponto de vista rítmico e harmônico ${ }^{11}$ (WILLET, 1967).

No Brasil, o jazz também insuflou novos ares nos cabarés e nos espetáculos de teatro de revista, à semelhança do que aconteceu em Portugal ${ }^{12}$. Como já foi atestado, no liquidificador sonoro das revistas ouviam-se, em regime de comunhão de bens culturais, sambas, maxixes, marchinhas e ritmos estrangeiros, principalmente de origem norte-americana. Contudo, como ressalvam pesquisadores do ramo (VENEZIANO, 1991, p. 48-50; RUIZ, 1984, 128-129), isso não implicava pura e simples cópia ou imitação do que vinha de fora. O escracho, por vezes, dava o tom, como na letra de uma canção, de título não identificado, interpretada por Araci Cortes na revista Às urnas, em 1929, no Teatro Recreio, do Rio de Janeiro. Num linguajar deliberadamente estropiado, se cantava, numa "adaptação" do idioma inglês difundido como nunca graças ao cinema falado que aterrissara no país em fins dos anos 1920:

\author{
Fut bol \\ Uetor pol \\ O espi kingles \\ Very uell tank yu \\ Ao ary yu \\ Ao love yu \\ Yess
}

Nessas circunstâncias, nem uma grande legenda da música popular brasileira ficou imune à sanha nacionalista. Pixinguinha, que integraria, posteriormente, o panteão da música nacional como um símbolo da tradição, seria, de certa maneira, indigitado como um exemplo de traição. Quem diria? Logo ele, em plenos anos 1920, se tornou objeto de comentários nada elogiosos por haver assimilado a influência das jazz bands. Isso se evidenciou após uma temporada de 6 meses na Paris de 1922, onde o conjunto Les Batutas se exibiu com Pixinguinha à flauta, ao lado de músicos que tocavam banjo, saxofone, clarineta, pistom e trombone, instrumentos pouco comuns às nossas tradições. Mais: as fotos dos batutas mostravam, pela própria disposição dos músicos, poses típi-

\footnotetext{
11 Essa realidade em movimento acendeu vivos debates sobre as relações entre música popular e erudita, algo que acompanhou igualmente a "era do jazz" nos Estados Unidos, como se vê em HOBSBAWM (1991, introd.).

12 Como eu verifiquei in loco, no desenrolar das minhas pesquisas referentes ao projeto PQ desenvolvido entre 2017-2020, Fado, um "inimigo nacional" na terra do samba? Lutas de representações no Brasil nos anos 1930. Ao me debruçar sobre o copioso material disponível na Coleção de folhas de músicas do Museu Nacional do Teatro e da Dança, em Lisboa, deparei-me com um sem-número de partituras de revistas em que variantes do "jazz", como one-step, fox, fox-trot, fox-slow e charleston suplantam, com folga, a quantidade de fados.
} 
cas das jazz bands estadunidenses. Algum tempo depois, Cruz Cordeiro (1928-1929), codiretor da revista Phono-Arte, denunciaria a influência da música norte-americana na melodia e na parte rítmica de "Lamento", "Carinhoso" e "Gavião calçudo". Ao escrever sobre este samba, o crítico era categórico ao emitir sua condenação: "Mais parece um fox-trot que um samba. [...] Tudo respira música dos 'yankees'"13.

Apagados esses fatos da memória, em 1954 a Revista da Música Popular, dirigida por Lucio Rangel e Pérsio de Moraes, dedicava a capa do seu número de estreia a Pixinguinha, saudado como modelo do "autêntico músico brasileiro, o criador e verdadeiro que nunca se deixou influenciar pelas modas efêmeras ou pelos ritmos estranhos ao nosso populário" (2006, p. 25). Detalhe: no seu rol de colaboradores figurava ninguém menos do que Cruz Cordeiro... Ironias da história.

\section{Guerra e paz nas fileiras nacionais}

A crer nas informações apresentadas por José Ramos Tinhorão, a calmaria voltaria a reinar nas hostes nacionalistas quando raiou a década de 1930. Para esse autor, "a volta da influência avassaladora da música norte-americana deu-se após uma trégua de 15 anos (os 15 anos de clausura política do Estado Novo), por volta de 1945, por força do falso princípio de reciprocidade instituído com a Política de Boa Vizinhança". (TINHORÃO, 1966b, p. 37) 14 .

Na verdade, a cada linha dessa citação há um equívoco a ser desfeito. Em primeiro lugar, a ditadura estado-novista não se estendeu por todo o período 1930-1945 (oficialmente, ela cobriu os anos 1937-1945), nem a política da boa vizinhança orquestrada pelos Estados Unidos foi deflagrada por volta de 1945 (ela aflorou na década de 1930), como Tinhorão deixa subentendido. O mais grave, no entanto, consiste em desconsiderar que, no que tange à propagação do fox-trot, este gênero musical expandiu o seu raio de penetração - se levarmos em conta os registros fonográficos - particularmente nos anos 1930.

Uma consulta à Discografia brasileira 78 rpm (SANTOS et al., 1982, vols. 2-3) evidencia que o fox-trot estava no topo da lista das músicas estrangeiras mais gravadas no Brasil entre 1930 e 1945 (na sequência vinham o tango e o fado, se excluídas as valsas). Ele inclusive servia de pau para toda obra ou todo tipo de acasalamento musical. As etiquetas dos discos arrolam uma diversificada gama de foxes: fox-canção, fox-cançoneta, fox-cowboy, fox-marcha, fox-sertanejo e... fox-samba. E se ouviram também foxes nacionais e estrangeiros, no original ou em versões (como as versões de João de Barro, Alberto Ribeiro, Lamartine Babo e Orestes Barbosa, muitas delas de filmes musicais estadunidenses). O versionista-mor do momento era Osvaldo Santiago, posto ocupado

\footnotetext{
13 Sobre o assunto, para maior riqueza de detalhes, ver MARTINS, 2014, p. 67-74, CAZES, 1999, cap. 8, e BESSA, 2010, cap. 5 e p. 208215. Uma das teses centrais desta autora assinala que, na sua formação musical, Pixinguinha cultivou uma escuta aberta a sonoridades de procedência variada, entre as quais a do jazz. Acrescente-se que, em entrevista concedida, em 1989, ao jornal Libération, João Gilberto, em pouco menos de duas linhas, reconheceu que "o jazz e a música americana em geral sempre influenciaram os músicos brasileiros", o que, como ele admite, ocorreu com Pixinguinha (apud GARCIA, 2012, p. 60).
}

14 Tal afirmação se conservou, ipsis litteris, na 3. ed., revista e ampliada desse livro, lançado 31 anos depois e reimpresso em 2002 (p. 50 ). 
por Haroldo Barbosa na década de 1940. Até o nacionalista e antilusitano por excelência Orestes Barbosa converteu-se, em meio a essa onda, em coautor de fox-canções e de fox-trots, em parceria com o maestro J. Tomás. Chegariam a compor um fox-samba, "Flor do asfalto"15, em 1931. Nesse terreno, todavia, como é voz corrente entre os pesquisadores, ninguém excedeu a Custódio Mesquita, com impecáveis composições em que dava mostras da assimilação criativa de procedimentos musicais norte-americanos, tal como em "Nada além" e "Mulher"16.

Armado esse cenário, compreende-se por que, já em 1930, num samba amaxixado de Randoval Montenegro, Carmen Miranda descarregava a ira dos nacionalistas contra o fox-trot e proclamava em "Eu gosto da minha terra":

Sou brasileira, tenho feitiço

Gosto do samba, nasci pra isso

O fox-trot não se compara

Com o nosso samba, que é coisa rara

Por outro lado, Noel Rosa, um dos maiores ícones do samba - senão o maior - da década de 1930, se juntava ao coro das vozes descontentes com o estado de coisas que apontava para a paulatina (embora bastante relativa) americanização do Brasil. Ele nem de longe compactuava com o modismo do fox-trot. Tudo o que the parecesse americanizado o desagradava profundamente, da mesma maneira como achava deplorável o brasileiro cantar em outras línguas. Nas palavras dos seus melhores biógrafos, "os estrangeirismos simplesmente não combinam com seu jeito de ser. São chiquês de grã-finos e intelectuais enfatuados, pura moda, mania de exibição". Daí seu nacionalismo popular, em linha direta com o que envolvia as classes populares: "Seu nacionalismo tem esse sentido. De gostar das 'coisas nossas'. De preferir o samba ao fox-trot" (MÁXIMO; DIDIER, 1990, p. 242) ${ }^{17}$. Seu ponto de vista foi sintetizado numa de suas obras-primas, "Não tem tradução", de 1933, em sua investida contra aqueles que, "dando pinote", só queriam "dançar o fox-trot". Seu desfecho é digno da maestria de Noel:

Amor lá no morro é amor pra chuchu As rimas do samba não são "I love you"

Esse negócio de "alô, alô, boy, alô, Johnny"

Só pode ser conversa de telefone

Nacionalista assumido, Assis Valente, um dos mais destacados sambistas dos anos 1930, repugnava igualmente os estrangeirismos. Ele aconselhava em "Good-bye"18, uma marcha gravada em 1933:

\footnotetext{
15 Sobre a defesa do samba e a luta do jornalista e poeta Orestes Barbosa contra a "invasão" do Brasil pelos portugueses e pelo fado, ver PARANHOS, 2017.

16 Em tempo: o maestro e arranjador Custódio Mesquita era, além do mais, um compositor de samba de mão-cheia. Ouvir, por exemplo, "Doutor em samba". Sobre o músico, ver BARROS, 2001.

17 nacionalismo popular de Noel, destituído de quaisquer traços ufanistas e grandiloquentes, é examinado por mim em PARANHOS, 1999, itens 1 e 2.

18 Sobre Assis Valente, ver SILVA; GOMES, 1988.
} 
Good-bye, boy,

Good-bye, boy

Deixa a mania do inglês

Fica tão feio pra você

Moreno frajola

Que nunca frequentou

As aulas da escola

Por sinal, na sua estreia em disco, em 1932, com "Tem francesa no morro", ele confiara a Araci Cortes, estrela cintilante do teatro de revista nas décadas de 1920 e 1930 , a missão de mostrar, com muita graça, que samba e "morrô" (ou seria "morreaux"?) não rimavam com França e, en passand, esculachava a língua francesa:

Vian

Petite francesa

Dancê le classique

Em cime de mesa

Alguns anos mais tarde, em Oui... oui..., Floriano Pinho bateria na mesma tecla:

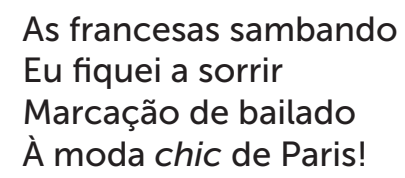

Decididamente, inúmeros exemplos poderiam ser colhidos para ilustrar como, entre 1930 e 1945, a música oriunda dos EUA continuou sua marcha por estas terras, o que, de resto, estava em sintonia com as novas rotas mundiais do capitalismo e da sua indústria de entretenimento (MOURA, 1984; TOTA, 2000). Num samba que atravessaria gerações, Assis Valente emplacou, no início dos anos 1940, um sucesso que, ao que tudo indica, foi encarado como um tanto quanto insolente e desafiador por Carmen Miranda, justamente a intérprete que mais jogou luz sobre a obra desse autor e que, em tempos de política da boa vizinhança, houve por bem não gravá-la. Como quem percebe que os pratos da balança das relações entre os Estados Unidos e o Brasil pendiam muito mais para o lado dos norte-americanos, Assis Valente, não sem certo sarcasmo, propôs que as coisas fossem recolocadas no devido lugar no esfuziante samba "Brasil pandeiro":

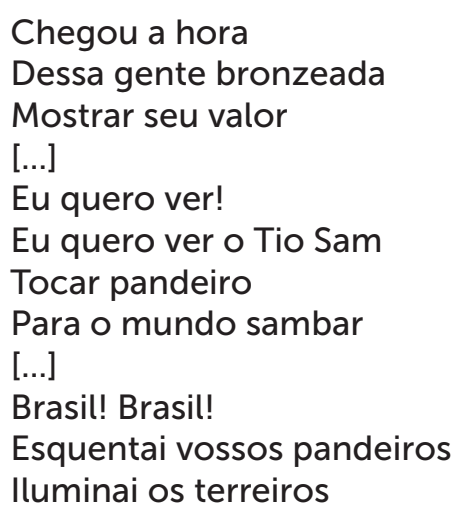




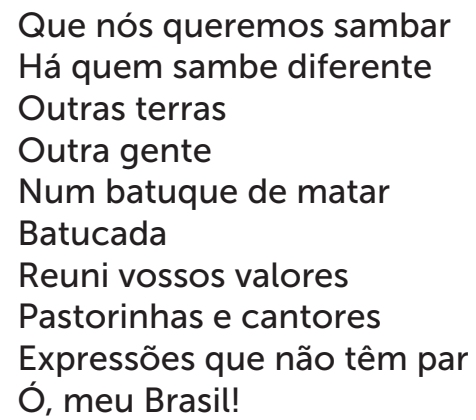

Na década de 1940, contudo, gravações embaladas por sons de "outras terras, outra gente" eram ouvidas até na instrumentação de sambas, como em arranjos produzidos por um dos mais conceituados maestros brasileiros, Radamés Gnattali. Sua orquestração para o samba-exaltação "Onde o céu azul é mais azul" é um desses exemplos. A introdução, na conjugação de metais, contrabaixo e bateria, soa às big bands norte-americanas, com a pulsação do jazz. E por aí vai o arranjo cuja sonoridade, com a harmonização à base de um naipe de metais, nos transporta, em outros momentos, para um contexto rítmico-timbrístico de além-Brasil, notadamente no final da execução, o que não deixa de estabelecer um contraponto crítico com o teor ufanista/nacionalista da letra ${ }^{19}$.

Na primeira metade dos anos 1940, a brasileira Leny Everson (nascida Hilda Campos Soares da Silva) começou a gravar como crooner de Anthony Sergi (Totó) e sua orquestra Columbia ou em discos solo, e se sucederam também as gravações de The Midnighters, grupo instrumental liderado por Zacarias, cujo crooner era Nilo Sérgio, que desenvolveria carreira em disco de 1945 em diante. Ambos cantavam em inglês, fosse fox-trot ou simplesmente fox. Data desse período ainda o que se poderia chamar de fox-símiles, casos de canções melodicamente bem elaboradas por José Maria de Abreu, como o fox-canção "Brigamos outra vez" (com acompanhamento de Fon-Fon e sua orquestra, gerando uma sonoridade à la EUA, ao promover o feliz casamento entre instrumentos de sopros e de cordas) e o fox "Eu, você e mais ninguém" (com acompanhamento ao piano de Carolina Cardoso de Menezes e seu quarteto, numa demonstração de pleno domínio da linguagem musical norte-americana).

Nesse campo, a mobilidade de fronteiras do samba iria se manifestar novamente. E ele, aos poucos, enveredava, uma vez mais, por territórios inexplorados, como prelúdio de tempos que estariam por vir, cenas dos próximos capítulos que desembocariam na Bossa Nova. Sob a rubrica de samba-swing, um compositor admirado por João Gilberto, Janet de Almeida, trazia o futuro para o presente. "Pesadelo", gravada em 1943, é rico em dissonâncias e recortes harmônicos pouco usuais no Brasil de então. Daí ao samba "Boogie-woogie na favela"20 (de Denis Brean, pseudônimo de Augusto Duarte Ri-

\footnotetext{
19 Naquela época, entre determinados adeptos do nacionalismo musical, a canção popular urbana era olhada de viés, sob uma pesada carga de preconceitos, porque estaria "sempre ameaçada pela 'conspurcação' estrangeira", como esclarece Orlando de Barros (2001, p. 359). Não foi à toa que, apesar de rasgar elogios ao talento de Radamés Gnattali, Mário de Andrade (1976, p. 286) ponderava, em 1939: "é certo que 'jazzifica' um pouco demais para o meu gosto defensivamente nacional". Heitor Villa-Lobos não ficava atrás: ele não simpatizava com o que soasse a "acordes americanizados", em descompasso com o "Brasil brasileiro" (apud BARROS, 2001, p. 360). Sobre Radamés Gnattali, ver BARBOSA; DEVOS, 1984, e DIDIER, 1996.
}

20 No mesmo ano foi lançado "Gosto mais do swing", no qual Lauro Maia propunha uma união por compatibilidade de gênios entre o sam- 
beiro), de 1945, o caminho a ser vencido era curto, a despeito da reação que, em honra às tradições nacionais, insistia em dar o troco em "Boogie-woogie não é samba".

\title{
"Música de boate" para "beautifull people"
}

Nesse contexto, o pano se levantou para a entrada em cena de um marco do samba-canção, "Copacabana", sucesso imediato na voz aveludada de Dick Farney (batizado Farnésio Dutra), cujo nome se devia à sua admiração por cantores estadunidenses como Bing Crosby. Nele o culto aos encantos da praia de Copacabana - cujo bairro se tornaria sinônimo da "era do samba-canção" - antecipava algumas das temáticas favoritas da Bossa Nova:

\author{
Tuas areias \\ Teu céu tão lindo \\ Tuas sereias \\ Sempre sorrindo
}

la para o ar uma canção embutida numa moldura harmônico-melódica com a sofisticação bossa-novista, que enaltecia o que já foi denominado "boemia solar": "pelas manhãs tu és a vida a cantar". Mas o que contava, acima de tudo, nesse quesito, era, efetivamente, a boemia noturna de Copacabana (MELLO, 2017, caps. 10-14; CASTRO, 2015).

Neste rápido e lacunar inventário de momentos marcantes da história da música popular brasileira, é imprescindível relembrar que o samba-canção, surgido no final da década de 1920 como samba de meio de ano, passou a dominar a noite do Rio de Janeiro a partir da segunda metade dos anos 1940 e, principalmente, na década de 1950, com sua "música de boate", que iria se espraiar por outros centros urbanos como São Paulo. Uma parcela tida como mais exigente do público consumidor de música, normalmente de extração social de classe alta e média ("beautifull people", frequentadores do "café society"), identificava nele uma coisa de "bom-tom", que convivia com a assimilação de componentes da música norte-americana. Apesar de descambar, às vezes, para o "sambolero" ou "sambalada" pouco significativos e, em casos extremados, conferir aos dramas humanos ares de dramalhão à mexicana, com direito a sangue e punhal, a produção mais consistente do samba-canção ${ }^{21}$ e o clima de intimidade que ele instalava propiciaram, até certo ponto, a aparição da Bossa Nova.

Música cantada em pequenos ambientes, associada frequentemente à cultura de fossa, as casas noturnas em que era ouvida serviram de escola para Tom Jobim e Johnny Alf, por exemplo, destaques nas noites cariocas e paulistanas. Cantores rotulados como

\footnotetext{
ba e o swing: "Nasci e sou do samba/ mas eu gosto do swing/ eu tenho a alma do fox dentro de mim [...]/ é o swing, de fato, verdadeira vibração/ quando o jazz rasga a música lá dum canto do salão". Em 1946, sob o rótulo de samba-boogie, a proposta de "Momo-boogie" era consumar uma relação inusitada no carnaval: "Agora a turma só pede/ samba com boogie [...]/ com o big-boogie-woogie/ todo mundo vai sambar". A propósito, ver CASTRO, 2007.

21 Frise-se que o primeiro Tom Jobim - para não me reportar aqui a outros compositores de peso, como Newton Mendonça - era escolado no samba-canção. Ouvir o CD Antonio Carlos Jobim: meus primeiros passos e compassos, do qual constam 23 gravações originais (de 1953 a 1956) de composições que levam sua assinatura (20 delas em regime de coautoria).
} 
"românticos", especialmente Dick Farney e Lucio Alves, lembrados como "precursores" pelos bossa-novistas, marcaram época nesse período. Compositora e cantora cercada de grande respeito, Dolores Duran era mestre no scat singing, no que viria a influenciar Leny Andrade, que até hoje a reverencia como sua "diva". ${ }^{22}$

Simultaneamente, Os Cariocas, um dos emblemas da Bossa Nova, já em 1948 esmeravam-se na ousadia de harmonizações dissonantes. Reprocessando elaborações de grupos vocais norte-americanos (notadamente os Modernaires e os Pied Pipers), eles se consagrariam, na opinião de muitos críticos e apreciadores de música, como o mais criativo conjunto vocal da história deste país. Suas duas primeiras gravações, o samba-canção "Nova ilusão" e o samba "Adeus, América", destoavam bastante da maneira como cantavam outros grupos, embora não se deva desconsiderar a relativamente inovadora atuação de conjuntos como Os Namorados da Lua, à frente do qual figurava o crooner Lucio Alves, familiarizado com as vocalizações de congêneres dos Estados Unidos.

O samba-canção expressava, como observou o crítico José Lino Grünewald, a internacionalização do samba "através do abandono da tipicidade dos instrumentos", enquanto "o ritmo se adapta a orquestrações com predominância de cordas" (apud PARANHOS, 1990, p. 25). E essas influências "estranhas" e "estrangeiras", incidindo sobre a perda de importância da percussão, iriam, obviamente, suscitar críticas: a reação ao samba-canção representou, sob diversos aspectos, a antessala da reação à Bossa Nova.

A atmosfera musical que imperava nas boates ficou sob a mira de muitos nacionalistas. Textos publicados na Revista da Música Popular ${ }^{23}$, em sua breve existência (1954-1956), ilustram notavelmente bem o descontentamento que grassava em relação à situação reinante. Ary Barroso, um dos mais festejados compositores brasileiros, não tinha papas na língua. Para ele, uma palavra resumia tudo: "decadência". E como isso era passivel de constatação? Ele enumerava seus argumentos:

2. Antigamente não havia 'acordes americanos' em samba. [...] 3. Antigamente não havia 'boites', nem 'night clubs', nem 'black tie' [...] 4. Antigamente não havia 'fans-clubs' [...] 5. Antigamente as orquestras [...] eram bandas autênticas" [...] 9. Antigamente samba era uma coisa, hoje é outra... 10. Decadência! Decadência! Decadência! (BARROSO, 1955, p. 463).

Proliferou, então, uma espécie de samba de uma nota só nas críticas encampadas pela revista. Cláudio Murilo (1954, p. 35), outro insatisfeito, ao deplorar o que designava como "espírito de imitação", era curto e grosso: "Positivamente, o músico brasileiro está com espírito de imitação. [...] No Brasil, toca-se 'be-bop', toca-se 'cool' e difundem-se as duas coisas". admirou. Ouvir o seu depoimento em "O negócio é amar", música de Carlos Lyra colocada sobre um poema póstumo de Dolores Duran caracterizado pelo tom francamente coloquial, muito ao seu estilo.

23 Por ora, considerados os limites de um mero artigo, faço tão somente uma pequena incursão em torno do que aí se pode encontrar acerca da presença do jazz nas práticas musicais adotadas no Brasil dos anos 1950. 
Se o quadro que se desenhava era desalentador, de acordo com esses porta-vozes do nacionalismo musical, o pior consistia em os brasileiros se deixarem enganar, comprando gato por lebre. Em outras palavras, em vez do "puro" e "verdadeiro" jazz, aquele que remetia ao início do século, produzido pelos negros de New Orleans, nós embarcávamos na canoa furada do "pseudojazz" (o bebop e o cool jazz), uma descaracterização do dixieland. Essa posição era explicitamente assumida pelos dois críticos que, em momentos distintos, atuaram como diretores da seção Jazz da Revista da Música Popular, José Sanz (1954, p. 60-81; 1955, p. 378-379) e Marcelo F. de Miranda (1955, p. 602-604)24. Ressalve-se que Jorge Guinle (1956, p. 706-707), um aficionado do jazz, que colaborava também com esse periódico, não partilhava dessas convicções, nem sequer das de Lucio Rangel; ele era, porém, uma voz solitária nesses assuntos ${ }^{25}$.

\title{
Proposta de armistício
}

O debate que girava ao redor da música popular iria se acirrar alguns anos mais tarde. Enquanto isso, já com a Bossa Nova na praça, provocando furor, um baiano, compositor e humorista, Gordurinha (por conta de sua magreza...), unia sua verve ao talento do paraibano Jackson de Pandeiro. Em 1959 ambos deram à luz o samba (sambaião, samba-roque ou o que for) "Chiclete com banana". Com toda a sua carga de humor, eles conceberam um desafio aos gringos que, na verdade, era uma proposta de convivência musical amistosa:

\author{
Eu só boto bebop no meu samba \\ Quando Tio Sam tocar um tamborim \\ Quando ele pegar \\ No pandeiro e no zabumba \\ Quando ele aprender \\ Que o samba não é rumba \\ Aí eu vou misturar \\ Miami com Copacabana \\ Chiclete eu misturo com banana \\ E o meu samba vai ficar assim: \\ Tururururururi bop-bebop-bebop \\ Tururururururi bop-bebop-bebop \\ Tururururururi bop-bebop-bebop \\ Eu quero ver a confusão \\ Tururururururi bop-bebop-bebop \\ Tururururururi bop-bebop-bebop \\ Tururururururi bop-bebop-bebop \\ Olha aí, o samba-rock, meu irmão \\ É, mas em compensação \\ Eu quero ver um boogie-woogie \\ De pandeiro e violão
}

\footnotetext{
24 Quanto aos discursos sobre o jazz e a cena musical de Copacabana da década de 1950, ver ainda SARAIVA, 2008.

25 Esse autor chega a mencionar "críticos por vezes superficiais (entre nós José Sanz, Lucio Rangel e M. Miranda)" (GUINLE, 1956, p. 707). Em 1953 ele escreveu o primeiro livro sobre jazz publicado por um brasileiro (GUINLE, 2002).
} 
Eu quero ver o Tio Sam

De frigideira

Numa batucada brasileira

Com muito molho, como que a exalar o tempero da Paraíba e da Bahia, a cozinha rítmica da gravação funde, na prática, chiclete (o bebop e o boogie-woogie) com a banana da terra (o samba e o baião, gênero que se difundiu enormemente pelo Brasil desde a segunda metade da década de 1940, capitaneado por Luiz Gonzaga), acrescentando pitadas de rock e de scat singing à moda da casa. Essa composição era uma falsa peça da artilharia musical nacionalista, como se percebe. Representava, isso sim, uma abertura para o diálogo artístico com gente de outras terras.

Não por acaso o tropicalista Gilberto Gil a regravou, em 1972, à semelhança do que fizera Caetano Veloso, em 1967, ao reaclimatar, numa perspectiva internacionalista, a nacionalista "Yes, nós temos bananas". ${ }^{26}$ Tinhorão e outros mais tinham tudo para ver nisso as artes do tinhoso. Estava tudo perdido! E a perdição tinha nome e sobrenome: Bossa Nova. Com ela, como uma nódoa aparentemente irremovível, a sombra tenebrosa do jazz continuaria a pairar sobre os destinos da música popular brasileira. Mas tal fato, enfim, como procurei evidenciar ao longo deste texto, não era exatamente uma novidade senão para os desavisados.

\section{Referências bibliográficas}

ANDERSON, Benedict. Comunidades imaginadas: reflexões sobre a origem e a difusão do nacionalismo. São Paulo: Companhia das Letras, 2008.

ANDRADE, Mário de. Música, doce música. 2. ed. São Paulo-Brasília: Martins/MEC, 1976.

BAKHTIN, Mikhail. Problemas da poética de Dostoiévski. Rio de Janeiro: Forense Universitária, 1981.

Marxismo e filosofia da linguagem. 11. ed. São Paulo: Hucitec, 2004.

BARBOSA, Valdinha e DEVOS, Anne Marie. Radamés Gnattali, o eterno experimentador. Rio de Janeiro: Funarte, 1984.

BARROS, Orlando de. Custódio Mesquita: um compositor romântico no tempo de Vargas (1930-45). Rio de Janeiro: Funarte/Eduerj, 2001.

BARROSO, Ary. Decadência. Revista da Música Popular, Rio de Janeiro, n. 9, p. 463, set. 1955 (edição em fac-símile).

26 Nesse registro, com arranjos de Rogério Duprat reambientando a canção nos moldes do dixieland, verifica-se, ao fim e ao cabo, uma demolição sonora da letra, que encena a exaltação do Brasil. O discurso nu de palavras fala mais alto e sepulta, no caso, o discurso literal: o nacionalismo vai para o ralo. 
BESSA, Virgínia de Almeida. A escuta singular de Pixinguinha: história e música popular no Brasil dos anos 1920 e 1930. São Paulo: Alameda, 2010.

BHABHA, Homi. Nation and narration. London: Routledge, 1990.

BLANNING, Tim. The pursuit of glory: Europe 1648-1815. Londres: Penguin, 2007.

Orgulho e preconceito nacional. In: O triunfo da música: a ascensão dos compositores, dos músicos e de sua arte. São Paulo: Companhia das Letras, p. 246-255, 2011.

BOLLOS, Liliana Harb. A Bossa Nova e a crítica: vozes dissonantes na imprensa. In: Bossa Nova e crítica: polifonia de vozes na imprensa. São Paulo: Annablume; Rio de Janeiro: Funarte, p. 145-236, 2010.

BOURDIEU, Pierre. A identidade e a representação: elementos para uma reflexão crítica sobre a ideia de região. In: O poder simbólico. 5. ed. Rio de Janeiro: Bertrand Brasil, p. 107-132, 2002a.

A representação política: elementos para uma teoria do campo político. In: O poder simbólico. 5. ed. Rio de Janeiro: Bertrand Brasil, p. 163-207, 2002b.

BRAIT, Beth (org.). Bakhtin, dialogismo e construção do sentido. Campinas: Editora da Unicamp, 2001.

CASTRO, Ruy. Hey-baba-re-bop! Quando o samba foi para a cama com o boogiewoogie. In: Tempestade de ritmos: jazz e música popular no século XX. São Paulo: Companhia das Letras, p. 370-377, 2007.

A noite do meu bem: a história e as histórias do samba-canção. São Paulo: Companhia das Letras, 2015.

CAZES, Henrique. Choro: do quintal ao Municipal. 2. ed. São Paulo: Editora 34, 1999.

CHARTIER, Roger. A História Cultural: entre práticas e representações. Rio de Janeiro: Bertrand Brasil; Lisboa: Difel, 1990.

CORBISIER, Roland. Formação e problema da cultura brasileira. Rio de Janeiro: Iseb, 1958.

CORDEIRO, Cruz. Comentários sobre "Lamentos", "Carinhoso" e "Gavião calçudo". Phono-Arte, Rio de Janeiro, nov./1928, jan./1929 e fev./1929. 
CORTI, Berenice. Jazz argentino, la música "negra" del país "blanco". Buenos Aires: Gourmet Musical, 2015.

DIDIER, Aluísio. Radamés Gnattali. Rio de Janeiro: Brasiliana, 1996.

FITZGERALD, F. Scott. Este lado do paraíso. São Paulo: Cosac \& Naify, 2003.

FOUCAULT, Michel. O que é um autor? In: Estética, literatura e pintura, música e cinema. 2. ed. Rio de Janeiro: Forense Universitária, p. 264-298, 2009.

GARCIA, Miliandre. Do teatro militante à música engajada: a experiência do CPC da UNE (1958-1964). São Paulo: Perseu Abramo, 2007.

GARCIA, Walter (org.). João Gilberto. São Paulo: Cosac Naify, 2012.

GILLER, Marilia. O jazz no Paraná entre 1920 a 1940: um estudo da obra "O sabiá", fox trot shimmy de José da Cruz. Dissertação (Mestrado em Música) - UFPR, Curitiba, 2013.

GONZÁLEZ, Juan Pablo; ROLLE, Claudio. Historia social de la música popular en Chile, 1890-1950. Santiago: Universidad Católica de Chile, 2005.

GRAMSCl, Antonio. Cadernos do cárcere, v. l: Introdução ao estudo da Filosofia. A filosofia de Benedetto Croce. 2. ed. Rio de Janeiro: Civilização Brasileira, 2001.

GUINLE, Jorge. Jazz: críticos e estilos. Revista da Música Popular, Rio de Janeiro, n. 13, p. 706-707, jun./1956 (edição em fac-símile).

Jazz panorama. 3. ed. Rio de Janeiro: José Olympio, 2002.

HOBSBAWM, Eric J. História social do jazz. 2. ed. Rio de Janeiro: Paz e Terra, 1991.

IKEDA, Alberto I. Apontamentos históricos sobre o jazz no Brasil: primeiros momentos. Revista Comunicações e Artes, São Paulo, v. 13, p. l11-124, 1984.

LABRES FILHO, Jair Paulo. Que jazz é esse? As jazz-bands no Rio de Janeiro da década de 1920. Dissertação (Mestrado em História) - UFF, Niterói, 2014.

MARTINS, Luiza Maria Braga. Os Oito Batutas: história e música brasileira nos anos 1920. Rio de Janeiro: Editora UFRJ, 2014.

MATOS, Maria Izilda Santos de. Dolores Duran: experiências boêmias em Copacabana nos anos 50. Rio de Janeiro: Bertrand Brasil, 1997. 
MÁXIMO, João; DIDIER, Carlos. Noel Rosa: uma biografia. Brasília: Linha Gráfica/UnB, 1990.

MELLO, Zuza Homem de. Copacabana: a trajetória do samba-canção (1929-1958). São Paulo: Editora 34/Sesc, 2017.

MENDÍVIL, Julio. La música y el nacionalismo. In: En contra de la música: herramientas para pensar, comprender y vivir las músicas. Buenos Aires: Gourmet Musical, p. 91-98, 2016.

MIRANDA, Marcelo F. de. Os "blues". Revista da Música Popular, Rio de Janeiro, n. 11, p. 602-604, nov.-dez./1955 (edição em fac-símile).

MOURA, Gerson. Tio Sam chega ao Brasil: a penetração cultural americana. São Paulo: Brasiliense, 1984.

MURILO, Cláudio. Revista da Música Popular, Rio de Janeiro, n. 1, p. 35, set./1954, (edição em fac-símile).

PARANHOS, Adalberto. Novas bossas e velhos argumentos: tradição e contemporaneidade na MPB. História \& Perspectivas, Uberlândia, n. 3, p. 5-111, jul.dez./1990.

O Brasil dá samba? Os sambistas e a invenção do samba como "coisa nossa". In: TORRES, Rodrigo (ed.). Música popular en América Latina. Santiago de Chile: Fondart, p. 193-232, 1999.

A música popular e a dança dos sentidos: distintas faces do mesmo. ArtCultura, Uberlândia, n. 9, p. 22-31, jul.-dez./2004.

Xô, fado! Nacionalismo e antilusitanismo na terra do samba. Tempo e Argumento, Florianópolis, vol. 9, n. 22, p. 44-69, set.-dez./2017.

A cruzada da purificação nacional contra a Bossa Nova: ecos de um debate. Revista de Estudos de Cultura, São Cristóvão, v. 4, n. 11, p. 19-36, jan.-maio/ 2018.

PUJOL, Sergio. Jazz al sur: historia de la música negra en Argentina. Buenos Aires: Emecé, 2004.

Cien años de música argentina: desde 1910 a nuestros dias. Buenos Aires: Biblos, 2013. 
Revista da Música Popular: coleção completa em fac-símile - setembro-1954 setembro-1956. Rio de Janeiro: Funarte/Bem-te-vi, 2006.

ROMERO, Silvio. Machado de Assis. Rio de Janeiro: Laemmert, 1897.

RUIZ, Roberto. Araci Cortes: linda flor. Rio de Janeiro: Funarte, 1984.

SANS, José. Gato por lebre. Revista da Música Popular, Rio de Janeiro, n. 1, p. 60-62, set./1954 (edição em fac-símile).

Jazz \& champanhota ou o colibri e a flor, Revista da Música Popular, Rio de Janeiro, n. 7, p. 378-379, maio-jun./1955 (edição em fac-símile).

SARAIVA, Joana. Da influência do jazz e outras notas: discursos sobre a cena musical de Copacabana dos anos 50. In: GIUMBELLI, Emerson; DINIZ, Júlio Cesar Valladão; NAVES, Santuza Cambraia. Leituras sobre a música popular: reflexões sobre sonoridades e cultura. Rio de Janeiro: 7 Letras/PPGSA-UFRJ/PUC-Rio, p. 83-97, 2008.

SCHWARZ, Roberto. Nacional por subtração. In: Que horas são?: ensaios. São Paulo: Companhia das Letras, p. 29-48, 1987.

SANTOS, Alcino; BARBALHO, Gracio; SEVERIANO, Jairo; AZEVEDO, M. A. de (Nirez). Discografia brasileira 78 rpm: 1902-1964, vols. 2 e 3. Rio de Janeiro: Funarte, 1982.

SEVCENKO, Nicolau. A capital irradiante: técnica, ritmos e ritos do Rio. In: NOVAIS, Fernando A. (dir.) e SEVCENKO, Nicolau (org.). História da vida privada no Brasil, vol. 3: República: da Belle Époque à era do rádio. São Paulo: Companhia das Letras, p. 513619, 1998.

SILVA, Francisco Duarte e GOMES, Dulcinéa Nunes. A jovialidade trágica de José de Assis Valente. Rio de Janeiro: Martins Fontes/Funarte, 1988.

SINIMBÚ, Renato Pinheiro. Os jazzes de Igarapé-Miri: dimensões culturais do entretenimento musical moderno no Baixo Tocantins (1940-1970). Dissertação (Mestrado em História Social da Amazônia) - UFPA, Belém, 2019.

SODRÉ, Nelson Werneck. Quem é povo no Brasil? Rio de Janeiro: Civilização Brasileira, 1962.

TINHORÃO, José Ramos. Marcha e samba. Revista Civilização Brasileira, Rio de Janeiro, n. 8, jul./1966a. 
Os pais da bossa nova. In: Música popular: um tema em debate. Rio de Janeiro: Saga, p. 17-22, 1966 b.

Os pais da bossa nova. In: Música popular: um tema em debate. 3. ed. rev. e ampl. São Paulo: Editora 34, p. 25-30, 1997.

Pequena história da música popular: da modinha ao tropicalismo. 5.

ed. São Paulo: Art, 1986.

TOTA, Antonio Pedro. O imperialismo sedutor: a americanização do Brasil na época da Segunda Guerra. São Paulo: Companhia das Letras, 2000.

VENEZIANO, Neyde. O teatro de revista no Brasil: dramaturgia e convenções.

Campinas: Editora Unicamp/Pontes, 1991.

WILLET, John. O teatro de Brecht: visto de oito aspectos. Rio de Janeiro: Zahar, 1967.

\section{Referências discográficas}

"Adeus, América" (Geraldo Jacques e Haroldo Barbosa), Os Cariocas. 78 rpm Continental, 1948.

Antonio Carlos Jobim: meus primeiros passos e compassos. CD Revivendo, s./d.

"Ave Maria Lola" (Sergio G. Siaba). Dolores Duran. 78 rpm Copacabana, 1959.

“Boogie-woogie na favela" (Denis Brean), Ciro Monteiro. 78 rpm Victor, 1945.

“Boogie-woogie não é samba" (Hélio Sindô), Hélio Sindô. 78 rpm Continental, 1945.

"Brasil pandeiro" (Assis Valente), Anjos do Inferno. 78 rpm Columbia, 1941.

"Brigamos outra vez" (José Maria de Abreu e Jair Amorin), Orlando Silva. 78 rpm Odeon, 1945.

"Carinhoso" (Pixinguinha), Orquestra Típica Pixinguinha-Donga. 78 rpm Parlophon, 1928.

"Chega de saudade" (Antonio Carlos Jobim e Vinicius de Morais), João Gilberto. 78 rpm Odeon, 1958.

Chega de saudade. João Gilberto. LP Odeon, 1959. 
"Chiclete com banana" (Gordurinha e Jackson do Pandeiro), Jackson do Pandeiro. 78 rpm Columbia, 1959.

Gilberto Gil. Expresso 2222. LP Philips, 1972.

"Copacabana" (João de Barro e Alberto Ribeiro), Dick Farney. 78 rpm Continental, 1946.

“Doutor em samba” (Custódio Mesquisa), Mário Reis. 78 rpm Victor, 1933.

"Eu gosto da minha terra" (Randoval Montenegro), Carmen Miranda. 78 rpm Victor, 1930.

"Eu, você e mais ninguém" (José Maria de Abreu e Saint-Clair Sena), Francisco Alves. 78 rpm Odeon, 1942.

“Fim de caso" (Dolores Duran), Dolores Duran. 78 rpm Copacabana, 1959.

"Flor do asfalto" (J. Tomás e Orestes Barbosa), Castro Barbosa. 78 rpm Victor, 1931.

"Gavião calçudo" (Pixinguinha), Patrício Teixeira. 78 rpm Odeon, 1929.

"Good-bye" (Assis Valente), Carmen Miranda. 78 rpm Victor, 1933.

"Gosto mais do swing" (Lauro Maia), Quatro Azes e Um Coringa. 78 rpm Odeon, 1945.

"Influência do jazz" (Carlos Lyra), Carlos Lyra. Depois do carnaval: o sambalanço de Carlos Lyra. LP Philips, 1962.

Carlos Lyra e Quarteto de Oscar Castro Neves. Bossa Nova at Carnegie Hall. Vários intérpretes. LP Audio Fidelity, 1962.

Leny Andrade. A arte maior de Leny Andrade. LP Polydor, 1963.

"Lamento" (Pixinguinha), Orquestra Típica Pixinguinha-Donga. 78 rpm Parlophon, 1928.

“Momo-boogie" (Denis Brean), Linda Batista. 78 rpm RCA Victor, 1946.

"Mulher" (Custódio Mesquita e Sadi Cabral), Sílvio Caldas. 78 rpm Victor, 1940.

“Nada além” (Custódio Mesquita e Mário Lago), Orlando Silva. 78 rpm Victor, 1938. 
“Não tem tradução" (Noel Rosa), Francisco Alves. 78 rpm Odeon, 1933.

“Nova ilusão" (Luiz Bittencourt e José Menezes), Os Cariocas. 78 rpm Continental, 1948.

"O negócio é amar" (Carlos Lyra e Dolores Duran), Leny Andrade. LP Leny Andrade, Pointer, 1984.

"Onde o céu azul é mais azul" (João de Barro, Alberto Ribeiro e Alcir Pires Vermelho), Francisco Alves. 78 rpm Columbia, 1940.

"Oui... oui..." (Floriano Pinho), Sônia Carvalho. 78 rpm Columbia (provavelmente de 1937).

"Pesadelo" (Janet de Almeida e Léo Vilar), Anjos do Inferno. 78 rpm Columbia, 1943.

"Tem francesa no morro" (Assis Valente), Araci Cortes. 78 rpm Columbia, 1932.

"Yes, nós temos bananas" (João de Barro e Alberto Ribeiro), Caetano Veloso. CS Philips, 1967. 